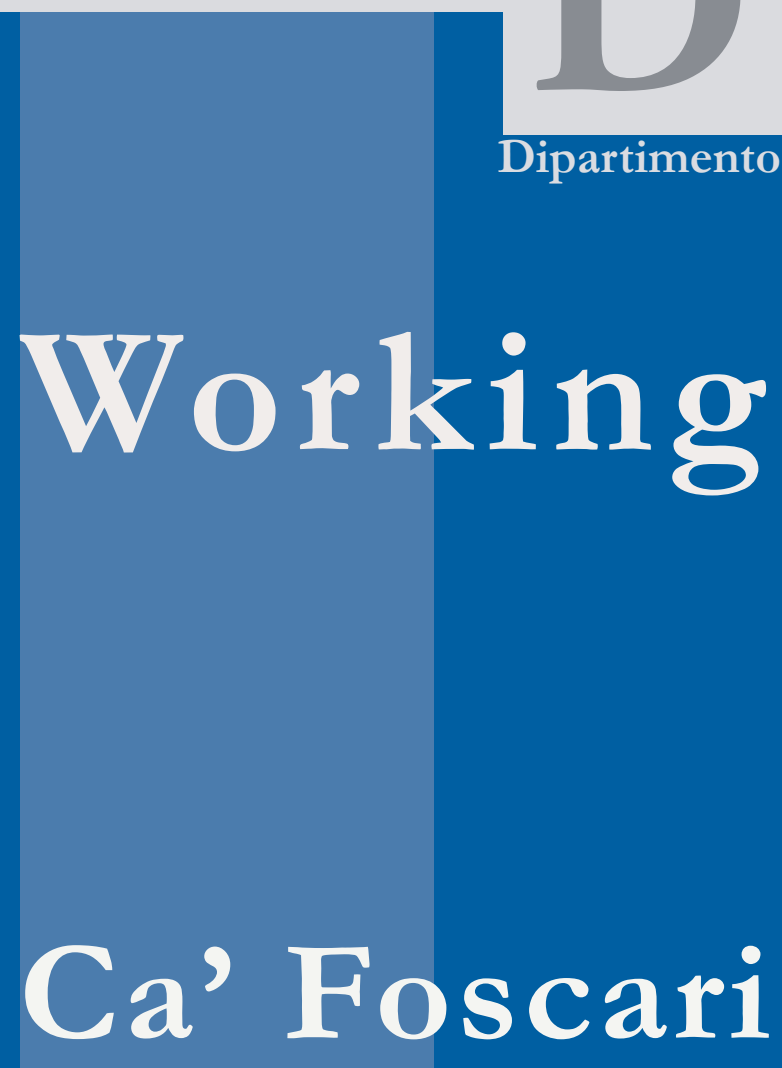

Paper

Department

of Economics

University of

Venice

Paolo Crestanello

Giuseppe Tattara

A Global Network and its Local Ties. Restructuring of the Benetton Group 


\title{
A Global Network and its Local Ties. Restructuring of the Benetton Group
}

\author{
Paolo Crestanello and Giuseppe Tattara \\ Università Ca’ Foscari Venezia
}

\begin{abstract}
The paper investigates the change in strategy of the Benetton Group, since the mid nineties, in face of the severe intensive competition in the international fashion market. New competitors, in particular the European brands Zara, Mango and H\&M, have challenged the Benetton position in the Italian and the European clothing market and have pushed the Group towards cost reduction through globalization of his suppliers.

Benetton is a vertically integrated producer that controls (in different ways) the whole value chain from textile raw materials to the sales to the consumers. Till 2000 Benetton made part of its production in its own factories and through a wide network of domestic subcontractors, mainly specialized in sewing. Now Benetton has drastically moved to a new strategy, abandoning Italy and organizing production around a dual supply chain: close locations (East Europe and North Africa) for quick production and far away locations (Asia) for more standardised products. The paper discusses also the redefinition of competences for the Treviso clothing district, where Benetton traditional sub-contractors have been in few years, drastically curtailed. Benetton restructuring marks the transition to a new network of competences between agents in the district.
\end{abstract}

\section{Keywords}

Global value chains, Internationalization, Benetton, Apparel.

\section{JEL Codes}

L22, L23, L67

\author{
Address for correspondence: \\ Giuseppe Tattara \\ Department of Economics \\ Ca' Foscari University of Venice \\ Cannaregio 873, Fondamenta S.Giobbe \\ 30121 Venezia - Italy \\ Fax: (++39) 0412349176 \\ e-mail: tattara@unive.it
}

This Working Paper is published under the auspices of the Department of Economics of the Ca' Foscari University of Venice. Opinions expressed herein are those of the authors and not those of the Department. The Working Paper series is designed to divulge preliminary or incomplete work, circulated to favour discussion and comments. Citation of this paper should consider its provisional character. 


\section{A Global Network and its Local Ties. Restructuring of the Benetton Group.}

\section{Introduction}

Since the 90s, the European clothing market has experienced a massive process of restructuring. There are several causes: from the modest growth of consumption caused by the stagnating income of Western countries in most recent years, to the appreciation of the Euro over the Dollar that refrained European exports and to the strong competition coming from low wage countries, particularly China after the abolition of clothing quotas (Adam 1971; Finger 1976-1977; Baden 2000; Graziani 2001). The consequences for the richer European countries have been a growing import of garments and the loss of hundreds of thousands of jobs in the domestic textile and clothing industry. Italy, as the only exception in the EU-15 countries, maintains a clothing trade surplus that is however diminishing with the time. In fact, between 1995 and 2007, the normalized Italian balance of clothing trade fell from $50 \%$ to $17 \%$ and during the same period the imports from China, as a share of total Italian imports, arose from $11 \%$ to $25 \%$.

In these last few years, the clothing market overall has appeared stagnant, but the companies who have adopted strategies based on quick response have grown faster than others have (Ciappei e Sani 2006:55). These companies have increased the variety of products that can be brought to the market in a short time. The fashion market is volatile and risky and consumers are incessantly stimulated to renew their purchases through a rich offer of new products. The successful marketer on the one hand needs to meet the variable fashion demand of the customer but on the other hand requires to build a network of fast and reliable suppliers (Gereffi 2005).

Fast fashion and production flexibility contrast with the necessity, especially for firms that are in the low or medium-end market, to produce at competitive prices. It is possible to reduce costs of production by sourcing to countries with lower wages, but importing from distant countries increases the time it takes to have the garments on the market and makes production less flexible. Consequently, the governance of the supply chain is now much more complex as it requires more efforts on design (to create a greater number of new products) and on controlling and managing distant suppliers (AbecassisMoedas 2006).

Benetton is one of the largest European garment producers and its core business consists of designing, producing and selling garments for men, women and children in wool and cotton. Its clothing production is marketed under several brands: "United Colors of Benetton", the flagship brand mainly for men and children, and Silsey, the fashion-oriented brand for women, represent respectively $77 \%$ and $18 \%$ of the total sales. Other minor brands,

\footnotetext{
${ }^{1}$ We wish to thank Pietro Arnaboldi, Mara Di Giorgio, Giuliano Franco, Diego Favaro, Lorenzo Zago of the Benetton Group staff and Tiziana Crosato and Sergio Spiller, of the Trade Unions, who provided us with the necessary information. We also thank participants to the Prin Bologna research group, to the Sase Meeting Copenhagen, 29 june 2007, and to other seminars held at the University of Venice, CDS Trivandrum, IDIS Delhi, Bank of Italy where a preliminary version of this paper has been discussed.
} 
"The Hip Side" for trendy, "Play Life and Killer Loop" for the leisurewear, cover the remaining $5 \%$.

Benetton, with Zara, is considered an exception in a context of large international brands mainly owned by pure retailers, such as Gap, H\&M and Mango, that do not own factories, but keep market relations with large independent suppliers (Tokatly 2008:23). Benetton is still renowned in the international literature to be a firm that manufactures the majority of its products in Italy (Berger 2005; Dicken 2006; Tokatly 2008). If this was true in the past, today it is no more. In the last five years, Benetton has quickly increased the process of production relocation abroad and at present only $20 \%$ of its products is manufactured in Italy, and it is foreseen that this percentage will halve in the next few years. The majority of the production is made in North Africa and in East Europe, but the recourse to the Asian producers, that did not appear in Benetton's suppliers list until 2003, is greatly increasing.

Parallel to this, the production planning has deeply changed. Up to 2003, production was entirely based on two seasonal collections and $80 \%$ of the orders from the retailers were received before the beginning of the selling season. The remaining $20 \%$ were mainly reorders and, only in small amount, orders of new products designed during the selling season. Today the number of collections has increased and the amount of orders received before the selling season has greatly decreased.

In the contest of broadening production variety, the increasing of foreign supplying, in particular from Asia, has deepened Benetton's logistic problems. Furthermore, the newly adopted strategies have had tangible consequences on the garment district of Treviso that in the last few years has greatly downsized.

\section{The roots of success: the period 1960-1970}

The firm Benetton was founded in 1965 at Ponzano Veneto, a small town near Treviso, by four brothers' initiative. In the beginning, Benetton was only a small company that was producing sweaters for local independent retailers. The keys to the success consisted in some innovations related to the product and its distribution and to an efficient production organization based on the work of a large network of small local subcontractors specialized in knitting, cutting and sewing garments. Right from the beginning, Benetton offered a new product characterized by bright colours and targeted to young people. The fully fashion knitwear was made on cotton looms and it was strictly in plain colour ${ }^{2}$. In this way it is possible to knit plain wool into sweaters and postpone dyeing the entire stock just before going to the market, according to the latest fashion trends. Retailers could order plain sweaters in advance and specify the colour during the selling season ${ }^{3}$. Together with the advantage of a rapid

\footnotetext{
${ }^{2}$ Carpi district, which had the Italian knitwear's leadership at that time, was instead specialized in a production of cut and sew knitwear with a very wide offer of models. So Benetton, differently from Carpi, offered a limited number of models, using the colours as strategy to differentiate its products (Brusco e Crestanello 1995).

${ }^{3}$ Gaeta in the introduction of Nardin's book (1987:8) defined the Benetton's organization as Fordist and the Ford's expression: "any customer can have a car painted any colour that he wants so long as it is black” could have been adapted in Benetton's case to: "any sweater he wants so long as it is basic and fully coloured".
} 
response to the fashion market, the dyeing postponement process allowed a drastic reduction of costs due to less expensive inventories and to a smaller unsold stock. This process was made possible thanks to an advanced dyeing process set up by Benetton, able to offer an wide number of colours and the guarantee that garments did not lose their colours when washed. Benetton internalized the dyeing process to take advantage fully of its dyeing know how (Dapiran, 1992).

Shortly after the production of knitwear, followed the production of shirts and jeans. In the beginning Benetton sold them under different brands (Tomato, Jeans West, etc.) because the quality of these new products was not yet comparable to the one obtained for the sweaters and there was a fear that it might damage the reputation that the firm had achieved as a knitwear producer.

It is estimated that in the second part of the seventies around $60-70 \%$ of the overall Benetton production was made by a hundred of subcontractors located mainly in Treviso and in the surrounding provinces of Veneto (Nardin 1987; Benetton and Lee 1990). The activities such as design, quality control and the manufacturing stages which required greater investments (such as knitting, cutting and dyeing), were instead undertaken in the two factories of Villorba and Monzambano which employed about 1000 workers.

From the very beginning, a tight control was imposed on subcontractors, to whom raw materials and precise technical details to make the garment were sent. The price paid by Benetton to its subcontractors was generally lower than the one paid by other firms, and it was updated yearly according to the rate of inflation. Lower prices, however, were compensated by the certainty and punctuality of payments, by long production runs (which could surpass 10 thousand items per model which was large for the market of the time) and by the guarantee of continuous orders that permitted the subcontractors to work at full production capacity (Brusco and Crestanello 1995; Crestanello 1996).

Parallel to the productive developments, Benetton carried out another revolution: it was the first Italian firm to apply a quasi-franchising system to retailing. This system permitted a fast growth of sales thanks to the fact that there was no need to have great financial resources to open new stores. That was good for Benetton that at the beginning of its success lacked the necessary capital.

The first Benetton's shop opened in Belluno in 1966 and in just few years Benetton's stores covered all Italian's provinces. In the beginning of the 70s, there were about 500 stores under different Benetton's brands (as well as Benetton, also Tomato, My Market and Merceria). The relationships with the retailers were similar but not equal to those of the franchising contract. In fact, there was not a written contract and royalties were not requested. On the other hand Benetton did not guarantee the retailers an exclusivity of territory, did not repurchase the unsold products and imposed the retail prices (Favero 2005:79). The shops, generally of small size constituted an innovation in the Italian market because they offered, at good price, good quality and highly fashionable sweaters which were displayed in a way so that customers were able to pick them up from the shelves, touch and try them. Even if the retailers worked with a limited mark-up, the selling activity was profitable as it guaranteed a 
high turnover per square meter and per worked hour ${ }^{4}$. The growth of Benetton depended more and more on the capacity to increase the number of stores under its own brands involving in the business some of its agents who became owners of many stores.

In those years, Benetton contributed to the creation of the casual style, targeted at the beginning for young people, but shortly after spread to other age groups. In the beginning almost all Benetton production was sold on the domestic market and exports became significant toward the end of the 70s with stores opened in France, Germany, United Kingdom, Holland and Belgium (Benetton Group Annual Report, 1990:112). Between 1973 and 1979, the Benetton's sales increased from 31 to 287 million Euros (Benetton and Lee 1990: 104).

In the seventies, thanks to Benetton and to other firms that followed the trail of its success, Italy became the major producer of knitwear in Europe. Another important producer of Treviso, Stefanel, in those years experienced a market success following the same Benetton's business model (coloured sweaters sold in franchising) and becoming very soon one of its main competitors.

\section{The period 1980-1990: growth by vertical and horizontal integration}

The 80s saw a passage from a family-owned company to a managerial one with the recruitment of a manager from outside the Ponzano factory ${ }^{5}$. The firm was quoted in Milano's stock's exchange in 1985 and later in the New York stock's exchange (from whose quotation it was withdrawn in 2007). In those years, an important role was played by the promotional campaigns carried out in collaboration with Oliviero Toscani who strengthened Benetton image, building an identity brand that was missing until then. The name "United Colors of Benetton" became the flagship brand of the Benetton Group.

Benetton grew through a strategy of vertical and horizontal integration. At the end of the 70s Benetton's organization could be defined as "quasi-verticalintegration" (Blois 1972) as the company controlled the whole value chain, even if various activities were not organized through an exclusive hierarchical control. In fact Benetton represented the main, if not the only, client of its subcontractors and could decide the price paid and the general terms of supply (Belussi and Festa 1990). As in the case of the franchisees, there was no a written contract and the orders were tacitly replaced at every season. Benetton established with its subcontractors long-term relationships based on cooperation and trust. Although there was an evident asymmetry in the negotiation power (subcontractors employed an average of 15-20 workers), Benetton, thanks to the constant growth of sales, was able to renew and increase the orders at every season, favouring the subcontractors who updated

\footnotetext{
${ }^{4}$ The mark up of Benetton's stores was $70 \%$ against an average of $100 \%$ applied by the other stores.

${ }^{5}$ In 1981, Aldo Palmeri, a Bank of Italy officer, became CEO of Benetton. Two years later, Giovanni Cantagalli, another manager coming from an American multinational company, was recruited in charge of personnel and shortly a team of managers was created to reorganize the Benetton's family-owned company.
} 
their equipment. Benetton used to advise its subcontractors about new machines that were most profitable and provided to some of them financial assistance through its leasing and factoring company.

It was at the end of the 80 s that Benetton started the process of entering directly into the upstream stages of the clothing value chain ${ }^{6}$. It acquired important textile and knitting factories through the affiliated company Olimpias that today owns, in several Italian provinces, ten plants supplying the majority of the raw materials necessary to the Group's clothing division. The control of the entire value chain was then completed: from retailing to clothing and textile manufacturing, to which also the wool production was added later. In 1991 in fact, the Benetton family acquired the company Tierras Del Sur Argentino, becoming the owner of 900 thousand hectares of breeding area for sheeps, for a total production of over 6 million kilos of wool ${ }^{7}$.

The process of horizontal integration was also achieved. The strategy of total look was completed with the introduction of products such as shoes, spectacles, perfumes, watches and, most recently, jewellery. This strategy was carried out both through acquisitions, as in the case of "Calzaturificio di Varese" in 1988, and through production licences as in the case of perfumes, spectacles and watches. In 1989 it was decided to enter into the sporting good sector with the acquisition (near Treviso) of Nordica, an important producer of boots, skis, skates, skateboard and tennis rackets. The new business was not successful and it was sold in 2003.

Until the 80s all the Benetton products were made in Italy. The beginning of Benetton's foreign production can be traced back to 1982 with factories established in France, Scotland and United States. The US factory was linked to a failed attempt to enter in the North American market (Nardin 1987:46). In the beginning of the 90s, the factories in Scotland and in the United States closed and two new plants opened in Spain and Portugal. The share of the foreign production rose to $20 \%$, a limited percentage if compared to that of other large Italian clothing brands. During the $90 \mathrm{~s}$, in consequence of the growth of sales the number of Benetton's Italian subcontractors increased and reached its maximum of 866 units in 2000. Therefore, in that period production remained mainly in Italy and the strategy of producing abroad, rather than for reducing costs, was driven by the desire to move production closer to the consumption market avoiding the currency exchange risk.

Starting from the second half of the 90s, Benetton faced an increase in competition, in particular from Zara, H\&M and Mango, whose products had generally lower prices ${ }^{8}$. The yarn and fabrics produced by Olimpias became expensive compared to the ones sold in the market. Furthermore, the export advantages due to the weak Lira exchange ended in 1995 with the decision of Italy to peg the Lira rate of exchange in order to enter the European Monetary

\footnotetext{
${ }^{6}$ In 1987 Benetton tried unsuccessfully to acquire Lanerossi, a large Italian textile company, which was its main supplier of carded yarn. The bidding winner was Marzotto that, after this acquisition, became the largest textile company in Italy.

${ }^{7}$ < benetton.linefeed.org/archives/000058.html>

${ }^{8}$ Zara is a vertical integrated firm both upstream, with factories located in Galicia, and downstream, with a large network of mono-brand stores. All the outlets transmit to the headquarters a continuous flow of information on their sell-out, allowing in this way a quick production response to the market's requests.
} 
Union two years later. The fixed exchange rate made impossible to Italian companies to transfer the increase of production costs on higher export prices and the progressive opening of the Eastern European markets to foreign investments induced Benetton to follow the strategy, already adopted by other Italian firms, to delocalize production first in Hungary, then in Rumania and Croatia ${ }^{9}$. Also Tunisia was interested by this process, mostly for cotton sweaters and jeans, in which this country is specialized. The manufacturing factories in France, Spain and Portugal lost their importance little by little and stopped their activity.

\section{The last decade: change of the collections time-table and productive internationalization}

At the beginning of 2000, Benetton speeded up the process of changing the production organization, in consequence of the strong competition mainly coming from Zara, H\&M and Mango, which are the main foreign brands to have their own stores in Italy.

The process of restructuring was extremely fast: in 2003, $48 \%$ of the volume of production was still manufactured abroad and $62 \%$ in Italy. Production abroad increased in just one year, between 2004 and 2005, by 13 million items and the employment in Benetton's Italian subcontracting firms shrank, from 2003 to 2005 , by 3100 workers ${ }^{10}$. This great shift was due to the decision taken in 2004 to move production to China. The recourse to Asian suppliers with a large autonomy in managing a broader range of manufacturing functions, including the sourcing of inputs and sometimes logistics, is described as "full package production". Benetton provides the design, often a simple sketch, and buys the final product that is delivered to its warehouse and then distributed to the stores. In 2007, Benetton's full package production represented, in terms of volume, $37.6 \%$ of the total ${ }^{11}$ and the increasing importance of this form of sourcing has made Benetton much more similar to the large clothing international retailers (e.g. H\&M, The Gap, Marks\&Spencer) than to a clothing manufacturer.

In 2005 Benetton's organization shifted from a system based on productive units referring to the different product categories (such as wool, cotton, etc.), to a structure based on the different activities (such as design, quality control, marketing etc); a move that underlines the change in the governance of the value chain (Annual Report 2006:24; Camuffo, Romano and Vinelli 2001). Also the structure and the number of collections changed radically. Until 2003, the production was based on two seasonal collections (Spring/Summer and Autumn/Winter) that were designed much in advance of the selling season and $80 \%$ of the production was decided on the basis of orders collected before the season by Benetton's agents. The remaining $20 \%$

\footnotetext{
9 According to Benetton in that period "the increase of Ebitda margins came from a significant reduction of industrial costs due to the production delocalization to East Europe" (Benetton, 2003)

${ }^{10}$ The loss of jobs was the result both of the closing of firms and the reduction of employees per firm. Furthermore, several subcontractors stopped working exclusively for Benetton and had to diversify their customers' portfolio to face a situation of uncertainty.

${ }^{11}$ Nowadays $90 \%$ of the Benetton's full package production comes from Asia.
} 
came from reorders. The products designed during the selling seasons "flashes" were a very small part of the production and were made just to "refresh" the shop windows. This organization did not permit taking advantage of the market opportunities, and was not encouraging consumers to pay more visits to the shops in search of the last fashion trends ${ }^{12}$. Following the success of Zara, able to offer constantly updated products in its stores, Benetton changed its collections timetable.

The traditional seasonal collection was split taking the names of Contemporary 1 and Contemporary2. Each one of these collections has a time-tomarket that varies between 4 and 8 months and is articulated in 4 launches: Spring, Summer, Autumn and Winter (Figure 1). Additionally, during the selling season, Benetton introduced three collections: "Trend" a collection more sensitive to the fashion tendencies with time-to-market between 1 and 4 months and the collections "Just in time" and "Continuative items" that use standardised raw materials ("Continuative items" is manufactured on stock) and are brought to the market in a very short time ( 7 days if the products are made in Italy and 15 days if imported from abroad). While "Iust in time" aims to satisfy fashion sensitive consumers, "Continuative items" guarantees that a collection's core products are restored in a very short while ${ }^{13}$.

The passage from a production planned well in advance to a flexible one, with a reduction of the time-to-market and an increase in the number of collections, required a new selling organization. The independent retailers, in fact, have to bear the risk of the end of season markdown and they put the orders only after having seen the products. There is in fact the need for the agents to visit the retailers more than one time a season to show the collections and this implies high transactional costs and difficulties in planning production. A direct control of the shops, instead, guarantees a better coordination of the entire value chain reducing the time needed for the independent retailers to decide their purchases. For this reason, Benetton, in the last few years, has increased the number of its own stores that now sell about a quarter of the value of total sales. Furthermore, in the last two years Benetton invested a great deal of resources in retailing activities, opening new stores in new markets, giving economic incentives to the franchisees and linking the production, logistic and retailing units through a new information system, in order to receive information about the sell-out and the retailers can have immediate confirmation and guaranteed delivery times for their orders ${ }^{14}$.

\footnotetext{
${ }^{12}$ Zara customers pay an average of 17 visits a year to the brand's shops, against an average of four visits for competitors (Gallaugher, 2008). Furthermore, it's a strong consumption incentive to know the product you see on the shelves might be no more available the day after.

${ }^{13}$ The two collections Contemporary1 and Contemporary 2 represent $75 \%$ of the annual production sold under the brand United Colors of Benetton. The collections Trend, Just in Time and "Continuative items" have instead a greater relevance for the fashion-oriented brand Sisley and they represent $50 \%$ of the total production under this brand.

${ }^{14}$ Starting from 2005 Benetton has renewed its informative system. Furthermore, Benetton monitors constantly what is selling and what is not in 500 mono-brand shops, to have a better production planning and to keep its inventory low.
} 
This shift of focus from production to retail activities confirms the transformation of Benetton from a manufacturing to a buying company ${ }^{15}$.

Figure 1 - New collections structure

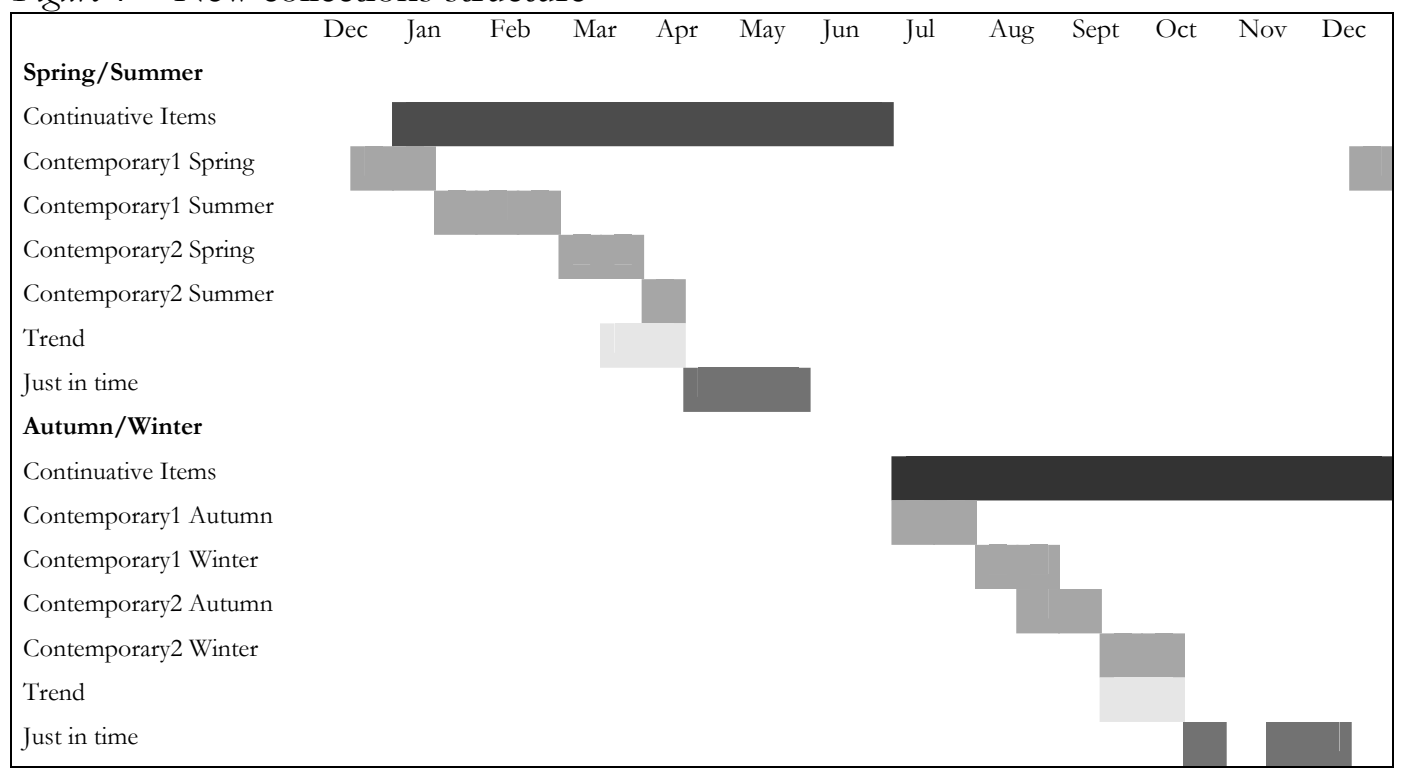

Source: Benetton website

\section{The present production organization}

In 2007, Benetton produced 145.2 million items (garments and clothing accessories, such as footwear, bags, belts, etc.), for a turnover of 1,856 million euros (Table.1). Other sales, concerning textile production sold to the independent clothing firms, royalties and other minor incomes, led the total Benetton's turnover to a value of 2,085 million Euros ${ }^{16}$. About half of the Benetton's production was sold in the Italian market, $36 \%$ in other European countries, $11 \%$ in Asia and a minor part in the Americas. Benetton sold its products in 124 countries $^{17}$ through 5800 mono-brand stores, 95\% of which are in franchising.

\footnotetext{
15 This change was anticipated in 2005 by the CEO Silvano Cassano who explained how Benetton was shifting investments from the manufacturing area to the retailing one (Benetton 2005). This strategy was also confirmed recently by a financial analyst: "Benetton is implementing new organisational procedures, with a better coordination among all the stages of the value chain, without focalising exclusively on the production efficiency. The result will lead to improve the variety of the offer and to reduce the lead time. Benetton is changing its own organisation with the focus on retailing and not on production ...” (Benetton 2007).

${ }^{16}$ Olimpias, the Benetton's textile company, sells 2/3 of its yarn and fabric production to the Group's clothing division and 1/3 to independent firms.

${ }^{17}$ More than 2000 shops are located in Italy, 2000 in other European countries, 500 in Asia and 250 in the Americas.
} 
Table 1 -Benetton Group turnover (in millions of Euros)

\begin{tabular}{lrrr}
\hline & 2007 & 2006 & 2005 \\
\hline Clothing, accessories and footwears & 1956.0 & 1715.1 & 1579.4 \\
Yarns and fabrics & 88.0 & 85.6 & 88.6 \\
Royalties & 41.0 & 11.9 & 15.5 \\
Others & - & 98.4 & 81.6 \\
Total & 2085.0 & 1911.0 & 1765.1 \\
\hline Source: Annual report: various years & & &
\end{tabular}

Source: Annual report: various years

Benetton owns only 300 stores that sell a proportionately larger amount of overall sale value, about $21 \%$. In order to keep relations with its many independent retailers Benetton maintains a large network of agents (some of them own several shops) coordinated by a team of area managers.

In 2007, the Group employed 8,896 workers of which 7,737 in various clothing activities such as textile (17\%) and retailing (42\%). 3,800 workers, $43 \%$ of the total, were employed in Treviso headquarters and in ten textile and knittig factories located in various parts of Italy.

The production activities are carried out by the Benetton's affiliate Benind, which governs, through its own subsidiaries, factories and logistic platforms in Hungary, Croatia, Tunisia, India (Tab. 2), and purchases full package products from the Benetton's Asian suppliers through the Group's trade company Asia Pacific.

Table 2 - Intra-trade between the Benetton's company Benind and its foreign affiliated companies in 2007 (in millions of Euros)

\begin{tabular}{|c|c|c|c|c|c|}
\hline & & $\begin{array}{l}\text { Purchases } \\
\text { of finished } \\
\text { products } \\
(1)\end{array}$ & $\begin{array}{c}\text { Sales of raw } \\
\text { material and } \\
\text { accessories (2) }\end{array}$ & $\begin{array}{r}\text { Manufacturing } \\
\text { value } \\
(3)=(1)-(2)\end{array}$ & Main activity \\
\hline Benetton Hungary* & Nagykálló & 183.1 & 74.6 & 108.6 & Garments and footwear \\
\hline Benrom Romania * & Sibiu & 36.8 & 18.7 & 18.1 & Cotton garments \\
\hline Benetton Croatia * & Osijek & 36.3 & 14.8 & 21.5 & $\begin{array}{l}\text { Wool garments, cotton knitwear, } \\
\text { dyeing }\end{array}$ \\
\hline Benetton Istria * & Labin & 62.9 & 30.9 & 32.1 & $\begin{array}{l}\text { Knitwear, wool garments, samples } \\
\text { (part of) }\end{array}$ \\
\hline Benetton Tunisia* & Sahline & 139.9 & 48.6 & 91.3 & Cotton garments, knitwear, dyeing \\
\hline Benetton Asia Pacific** & Hong Kong & 231.0 & - & - & $\begin{array}{l}\text { Cotton garments, knitwear and } \\
\text { accessories }\end{array}$ \\
\hline Benetton India* & Gurgaon & 2.3 & 0.2 & - & Cotton garments \\
\hline Total & & 692.2 & 187.7 & & \\
\hline
\end{tabular}

*outward processing production; **full package production; Source: Annual Report. Benind Spa, 2007: 4344

The garments manufactured abroad are imported from Benind and then sold to Bencom (the commercial division of the Group), which distributes them to the stores. In 2007 Benind sold raw materials to its foreign affiliates (Benetton India and Asia Pacific excluded) for 188 million Euros and imported from all foreign companies finished garments and clothing accessories for 692 million Euros. In the same year, Benind purchased garments from Italian subcontractors and paid dye-work services for a total of 103 millions. 
In 2007, 32.4\% of Benetton's production, in terms of volume, was produced in Asia, $20 \%$ in Tunisia and $28.5 \%$ in East European countries. Italy produced only $10.3 \%$ (Table 3 ).

Figure 2-- Percentage distribution of garments and accessory items produced by Benetton (number of items)
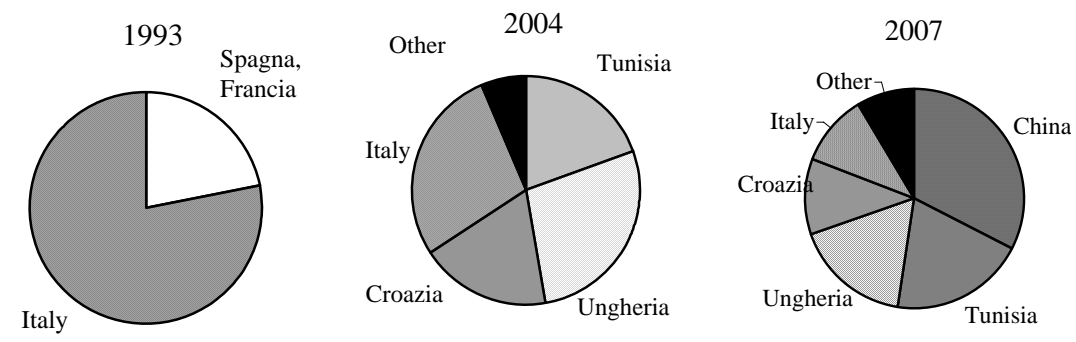

Table 3 - Number of garments and accessory items produced by Benetton

\begin{tabular}{lrrrr}
\multicolumn{4}{c}{2006} & \multicolumn{2}{c}{2007} & $\%$ \\
\hline Italy & Million of items & $\%$ & Million of items & 10.3 \\
Eastern Europe & 19.7 & 14.9 & 15.0 & 28.5 \\
Tunisia & 43.0 & 32.5 & 41.4 & 20.0 \\
Asia & 26.1 & 19.7 & 29.0 & 32.4 \\
Other countries & 34.9 & 26.3 & 47.1 & 8.7 \\
Total & 8.8 & 6.6 & 12.7 & 100.0 \\
\hline Source: interviews with Benetton staff & 132.5 & 100.0 & 145.2 &
\end{tabular}

The choice of the outsourcing countries depends on several factors: labour cost, economic and fiscal incentives, availability of skilled labour, flexibility and time-to-market. Shifting production from Europe to Asia has cut the unit cost of production because of the lower cost of labour, the use of cheaper local raw materials, and because several Asian countries have their currencies linked to the weak dollar ${ }^{18}$. The increasing full package imports from Asia have reduced, as well, transactional costs simplifying the control of the production value chain. From 2003, in spite of the presence of a yearly sale growth of $8-9 \%$, and even if a large part of production moved to Asia was to the detriment of East European countries, there has been a further reduction in the level of activity performed in Italy. This is because the recourse to full package production reduces the activities carried out by Italian workers (employed both by Benetton and by its subcontractors) such as quality control and logistics that were connected to the sourcing of part of the manufacturing production in Tunisia and in Eastern Europe. In addition, the amount of raw materials produced by the Benetton textile-knitting division and sent to the European and Tunisia factories, has declined and this has further reduced the value of production made in Italy.

At present, Benetton's production is organized according to two supply chains (figure 3). The first one uses Italian, European and Tunisian suppliers to

${ }^{18}$ According to an interview carried out to a manager of Benetton, the production delocalised in India has permitted to reduce the production costs of $20 \%$ (see also $\mathrm{Na}$ Thalang , 2007). 
produce fast fashion and more complex products, while the second one employs Asian suppliers for more standardized production, made on long runs and planned in advance. The majority of Asian production is imported in Treviso where, thanks to a fully robotized warehouse, is efficiently stocked and sent to the worldwide shops. The warehouse in Shangai serves mainly the Asian markets.

Figure 3 - The global value chain of the Benetton Group.

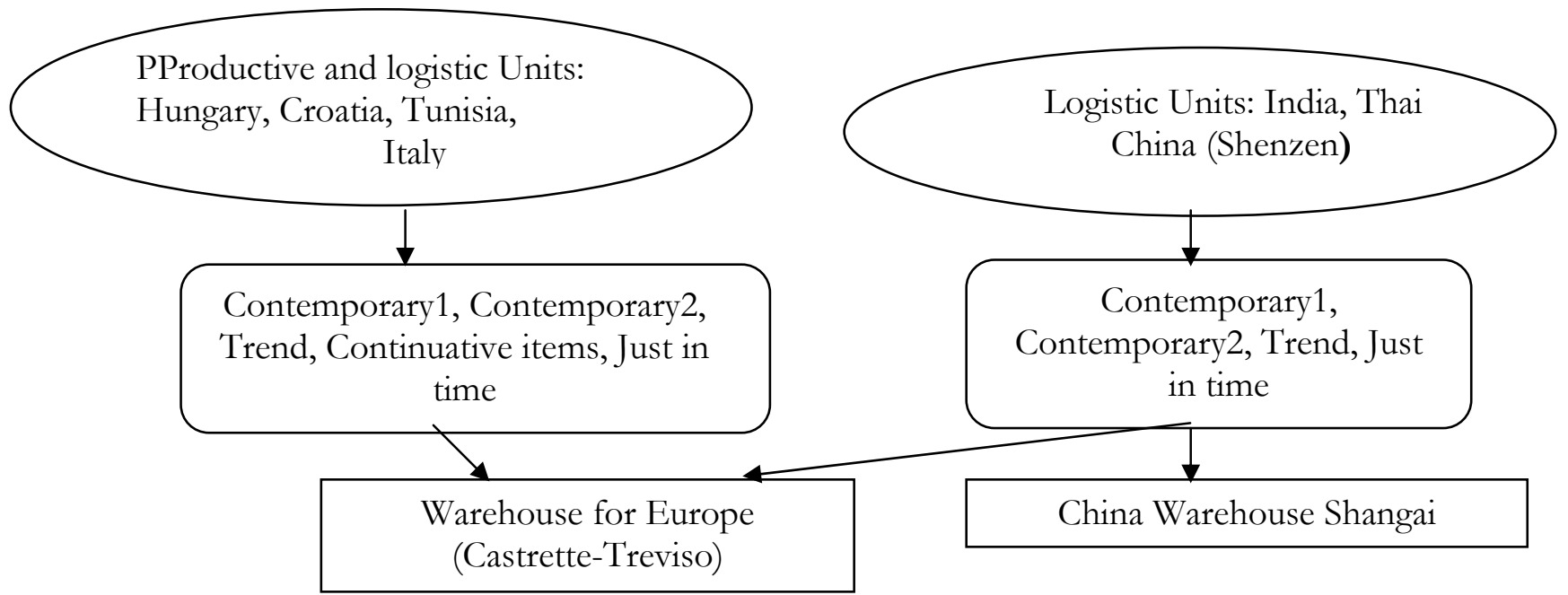

Source: interviews with Benetton Staff

\section{The Italian production}

Between 2003 and 2007 the Italian share of Benetton's production, in terms of volume, shifted from 38\% (41.3 millions of units) to 10.5\% (15 millions of units) with a reduction of 26.3 millions items ${ }^{19}$ (Table 4$)$.

Table 4 -Benetton's Italian subcontractors. Number of firms, employees and production items

\begin{tabular}{|c|c|c|c|c|c|c|c|}
\hline \multirow[t]{2}{*}{ years } & \multirow{2}{*}{$\begin{array}{l}\text { Production } \\
\text { total }\end{array}$} & \multirow{2}{*}{$\begin{array}{c}\text { (millions) } \\
\text { Italy }\end{array}$} & \multicolumn{2}{|c|}{ Italian subcontractors } & \multicolumn{2}{|c|}{ Production } & \multirow{2}{*}{$\begin{array}{c}\text { Employees } \\
\text { per firm }\end{array}$} \\
\hline & & & firms & employees & Italy/total & per firm & \\
\hline 2003 & 108.7 & 41.3 & 525 & 8249 & $38.0 \%$ & 78667 & 15.7 \\
\hline 2004 & 109.4 & 30.6 & 458 & 5884 & $28.0 \%$ & 66812 & 12.8 \\
\hline 2005 & 113.0 & 20.3 & 327 & 5136 & $18.0 \%$ & 62080 & 15.7 \\
\hline 2006 & 134.0 & 18.0 & 351 & n.a. & $13.4 \%$ & 51282 & n..a. \\
\hline 2007 & 145.2 & 15.0 & 295 & n.a. & $10.5 \%$ & 50847 & n.a. \\
\hline
\end{tabular}

\footnotetext{
19 The average value per garment is higher in Italy than in the foreign countries, because of the more complex product made by Italian subcontractors.
} 
Between 2000 and 2007 the number of Benetton's Italian subcontractors has shrunk from 580 to 295, while the number of employees, between 2003 (first year for which data are available) and 2005, has declined from 8249 to 5136. In the last three years, the number of subcontracting firms in Treviso diminished from 208 to 116, while their employment in 2005 (last available data) was of 2085 units (Table 5). At present $80 \%$ of Benetton's Italian subcontractors are located in Veneto.

Between 2003 and 2007 the average dimension of the Benetton's orders per subcontracting firm fell from 79 thousand to 51 thousand items, a volume of production that a subcontractor of average size (15 employees) can deal in 3-5 months. The majority of the firms, that in the past used to work exclusively for Benetton, has now diversified their client's portfolio. Furthermore, the only orders which remain in Italy are products made on small runs and with short delivery time. Nowadays, Italian subcontractors have the role to guarantee flexibility to the value chain, solving problems that arise in dealing with distant sourcing: transport delays, errors in production plans, product faults, etc..

In $2006,37 \%$ of Benetton's Italian suppliers was located in Treviso where it represented a share of $30 \%$ of the number of the clothing subcontractors with an employment share of $40 \%$ in 2004 (last available year). We can estimate that in 2006 the number of garments produced in Treviso was about 2 million items (Crestanello, 2008). In the headquarters and in the robotized warehouse located in the surroundings of Treviso, Benetton employs 1,800 workers involved in design, marketing and logistic activities.

Tab.5 - The Benetton's Italian subcontracting firms and their employees

\begin{tabular}{cccccc}
\hline & & Italy & & $\begin{array}{c}\text { Veneto region } \\
\text { firms }\end{array}$ & \multicolumn{2}{c}{ Province of Treviso } \\
firms & employees \\
\hline 2000 & 768 & - & 580 & 283 & - \\
2003 & 525 & 8249 & 395 & 208 & 3147 \\
2004 & 458 & 5884 & 354 & 181 & 2464 \\
2005 & 327 & 5136 & 272 & 137 & 2085 \\
2006 & 351 & n.a. & 276 & 132 & n.a. \\
2007 & 295 & n.a. & 240 & 116 & n.a. \\
\hline
\end{tabular}

Source: Trade Unions

\section{Production in Eastern European countries and in Tunisia}

Benetton owns in Europe five logistic-productive platforms: 2 in Hungary, 2 in Croatia and 1 in Tunisia. Raw materials are distributed from Italy to the local subcontractors mainly specialized in sewing, ironing, wrapping the final product that is sent back to Italy ready to be distributed to the shops. In Tunisia and in European countries all the production occurs according to an outward processing model that uses raw materials sent from the buyer and requires a continuous technical assistance to keep up the quality and fulfill the delivery times. This is possible thanks to the presence of skilled employees placed at the end of the productive lines (Pickles et al. 2006; Crestanello and Tattara 200). In 2007, the five platforms of Benetton employed 1047 workers and the relative value chains involved 312 foreign suppliers with 19,500 workers (Tab. 6). The average size of the foreign firms is three times bigger than that of the firms that work for Benetton in Italy and the reduction in 
number of subcontractors is undoubtedly an element of organizational simplification.

In these countries there are several Italian entrepreneurs who have been convinced by the Benetton's management to transfer abroad their activities, so to be able to continue to work for the Group; on the contrary their orders would have been interrupted (Crestanello and Tattara 2005).

Tab. 6 - Benetton's logistic platforms and subcontracting firms in East Europe and Tunisia, 2007

\begin{tabular}{lrrrr}
\hline & $\begin{array}{r}\text { Benetton } \\
\text { employees }\end{array}$ & $\begin{array}{r}\text { Employees in the } \\
\text { subcontracting } \\
\text { firms }\end{array}$ & $\begin{array}{r}\text { Number of } \\
\text { employees per firm }\end{array}$ \\
\hline Hungary and Romania & 281 & 126 & 9200 & 73.2 \\
Croatia & 375 & 43 & 2800 & 65.1 \\
Tunisia & 391 & 143 & 7500 & 52.4 \\
Total & 1047 & 312 & 19500 & 62.5 \\
\hline
\end{tabular}

Source: Interviews

\section{East Europe}

41.4 million garments are produced in the Eastern European countries, equal to $28.5 \%$ of the whole volume made from Benetton. Production is organized by four logistic-productive platforms. The ones of Nagikallo in Hungary and of Sibiu in Romania employ 281 workers and manage a network of 126 suppliers localized in several Eastern Europeans countries (Hungary, Romania, Poland, Moldavia, Slovakia and Ukraine) for a total of 9,200 employees. In addition, the Hungarian plant carries out cutting and printing operations. The third and fourth platforms are located in Croatia (Osijek and Labin) and make dyeing and knitting, employing 375 employees. The garments production is made by 43 local suppliers with 2,800 employees $^{20}$.

In the last few years, production in Hungary has started to decline ${ }^{21}$, while that in Croatia has increased specializing on fast response production. For this reason Croatia today has become a formidable competitor for Italian subcontractors (Crestanello 2008).

\section{Tunisia}

In Tunisia, the local network of subcontractors, mainly specialized in sewing and upstream operations, is managed by the Benetton's platform of Sahline. Here Benetton owns two factories with 391 workers which make cotton fabric, knitting, dyeing and special finishing (like printing, stone wash, stone bleach, etc). The subcontractors' network is made of 143 firms employing 7,500 employees that produce yearly 29 millions of garments, mainly knitwear.

The production in Tunisia has recently increased and 20 million Euros are to be invested in a new factory that will produce knitted cotton fabrics. The new production, estimated in 3.6 million kilos will serve local subcontractors, with a decline in unit cost and increase in efficiency (the network forecasted

\footnotetext{
${ }^{20}$ In 2000 the Osijek factory received 24 large looms from the Benetton's factory of Troyes (France) which was closing.

${ }^{21}$ The tens of years of fiscal benefits of the Hungarian factory are ending and this, together with the abandonment of the sporting goods production (made in this factory), explain the progressive loss of importance of this productive pole.
} 
production will increase of 21 million garment units). The present preference toward the Tunisian suppliers rather than the Eastern European ones is due to the fiscal benefits allowed to the new factories ${ }^{22}$, to a lower and stable cost of labor and to the high competences available in Tunisia .

\section{Production in Asia}

In Asia production is commissioned to more autonomous local subcontractors which purchase directly the necessary raw materials, often from selected producers, whose production process is monitored by Benetton. In East Europe and in Tunisia the subcontractors receive the fabric (made in Italy or in other countries as Turkey) directly from Benetton and all accessories as well with a detailed manufacturing schedule.

In Asia are produced, as well as garments all Benetton's accessories such as shoes, bags belts, umbrellas, toys, perfumes, etc. The imports from Asia have largely increased in the last few years and today they represent in terms of volume 47.1 million items equal to $32.4 \%$ of Benetton's total production ${ }^{23}$. Benetton's network of Asian suppliers is managed by Asia Pacific, an affiliated trade company established in Hong Kong, which controls the logistic platforms of Shenzhen and Shanghai. Only a small part of the products manufactured in Asia is sold on the domestic market, the majority is imported in Italy (231 million Euros over a total of 248).

A growing amount of Asian production is manufactured in Vietnam, Cambodia and Bangladesh and is governed by the recently established logistic platform of Bangkok. At present, the number of garments produced in these three countries is around two million items, with a forecasted reach of 18 million items by 2011. The increase of production in these countries is explained by a labor cost which is lower than that of China. Full package production makes the outsourcing organization simpler and, in the case of standardized products made on stock, such as a great part of the accessories, permits a short delivery time too ${ }^{24}$.

In India production occurs according to a network model that combines vertical integration and subcontracting. In Gurgaon (close to New Delhi) the Benetton's factory employs 300 workers and organizes the work of many local subcontractors that employ 5,000 workers. The subcontractors receive the raw materials and a precise technical schedule and they produce about $50 \%$ of the entire Benetton's Indian production. Differently from China, almost all the production made in India (about 6 million units) is targeted to the domestic market ${ }^{25}$.

\footnotetext{
${ }^{22}$ In Tunisia Benetton and other clothing firms like The Gap, Lee Cooper and Yves Saint Laurent benefit duty exemptions on imports, low VAT on the imported capital goods, low taxes on profits (and total exemption on the reinvested profits) and other incentives (Tunisie 2008).

${ }^{23}$ It has to be considered that in 2004 Benetton imports from Asia were only 14 millions of Euro against 231 millions of 2007.

${ }^{24}$ As Benetton says: "A particular attention is given to the full package production that regards specific markets, such as China. The expansion of this production has produced a competitive advantage in terms of lower costs and shorter lead time" (Annual Report, $2004: 9)$

${ }^{25}$ It mainly produces clothing for children and apparel accessories
} 


\section{New markets and production partnerships}

Benetton's strategy not only aims to reduce production costs, but also to expand the number of mono-brand stores, mainly in new markets which offer better business opportunities. In the last few years, in fact, the Russian, Turkish and Asian markets, to which the Mexican market joined more recently, have sustained Benetton's sales. The rate of growth of Benetton revenues in these markets has been $27 \%$ in 2008 (nine months) and $40 \%$ in 2007 while revenues in Europe have grown respectively at 4\% and 12\% (Nine Months Report, 2008:7, Annual Report, 2007:17). In China, at the end of 2006, Benetton has opened more than 100 shops and two mega-stores in Shanghai and Beijing. In India where Benetton is present since 1990, 106 shops have been opened in 43 towns, while in Russia the $150^{\text {th }}$ shop was inaugurated in 2007 (Annual Report 2007:17).

In the last two years economic resources have been invested to open new stores managed directly by Benetton. The majority of these new shops has been set up in the new markets such as India, Korea and Russia, where the franchising system is difficult to introduce.

In some countries Benetton uses productive and commercial partnerships to expand faster its presence. In China, an agreement has been signed with Hemply International Company which will open 150 Sisley shops in the next five years. In India, Benetton's garments are distributed thanks to a deal with the Trent company, which is part of the Tata Group, while in Mexico a commercial agreement has been made with the distribution company Sears. As regards the licensed productions ${ }^{26}$, Benetton has two agreements in Turkey: one is concerning house products under the Sisley brand with the Zorlu Group, leader in this sector, the other one with the Boyner Group for the production and distribution of garments also in the Turkey neighbouring countries.

\section{Conclusions}

In the seventies Benetton's competitive advantage was grounded on product innovations based on the use of bright colours, on delaying the dyeing process as long as possible and on the ability to manage a network of small subcontractors located in important industrial districts of Italy. These firms were linked to Benetton by an exclusive pact and by informal and long-term relationships based on trust. Production costs were relatively low - at that time Italian wages were noticeably much lower than the French and the German ones - and Benetton's subcontractors benefited from long production runs and working at full production capacity. Benetton in fact granted a constant flow of orders to its suppliers that could confidently make new investments and update their machinery.

The Benetton success has been inextricably linked with the development of the Treviso district where the largest share of Benetton production was traditionally localized. The innovations that were at the roots of its success have developed from immersion in the crafts of production, in the close

${ }^{26}$ Benetton production licences regard different products: spectacles, perfumes, house products. 
contacts with people who had a daily practice with design, machinery, raw materials and accessories ${ }^{27}$. At the same time the familiarity that derived from the direct selling experience of Luciano Benetton has contributed to build a retail structure that, without direct capital investment, mushroomed in few years and now is one of the largest retail structures in the European clothing market ${ }^{28}$.

During the last decade and under a strong competitive pressure, Benetton has focused more attention to the price, moving a large share of its production abroad, and to the need to change the timetable of its collections, introducing many new products during the selling season. There is an evident trade off between these two targets. While the recourse to cheap foreign suppliers risks to increase the delivery time and creates rigidities in production organization, a shorter life product cycle requires more flexibility.

This more complex organization requires a tight and efficient integration between the production, logistic and retailing activities. A difficult task if, as in the case of Benetton, the large majority of mono-brand shops is run by independent retailers. To face this challenge Benetton has increased the number of its own shops and at the same time has recently granted to the independent retailers greater mark-up margins (bearing a heavy cost) in order to strengthen the retail network and receive from the retailers a better feedback (information on sell-out, support for the many seasonal proposals, etc.) (Annual Report, 2007:42). The retail network has so experienced a process of increasing hierarchical control; whereas the production organization is moving towards arm's-length market relations, phenomenon confirmed by the large amount of full package production outsourced abroad, mainly from Asia.

Such a radical shift of focus from production to retail activities has required new competencies and has changed the relationships with the economic actors in the different stages of the supply chain. In particular, this change has negatively impacted on the clothing district of Treviso where the largest share of Benetton production was traditionally localized. Not only the number of Italian Benetton's subcontractors has reduced, substituted with foreign low wage suppliers, but also the relationships based on trust, that had in the past linked the Group to its subcontractors, are now much weaker. Many of these firms have diversified their client's portfolio and now Benetton is no more their exclusive buyer. The clothing district of Treviso is today specialized in activities such as design, quality control, logistic, marketing and in producing short runs with quick delivery times, having lost the large volumes of production that Benetton and other leading brands now get from abroad ${ }^{29}$.

\footnotetext{
${ }^{27}$ The second generation of Benetton's managers (and the sons of the four Benetton founders with them) do not have the same level of familiarity with the tools and materials than their parents had when they started the business.

${ }^{28}$ See Lane 2004, for an approach to the district as an evolving structure under pressure from globalization.

29 Nowadays local producers deal with high fashion and more sophisticated products, such as seamless garments, and relatively capital intensive manufacturing operations such as CAD-CAM, dyeing and printing (Gomirato 2004).
} 


\section{Bibliography}

Abecassis-Moedas C. (2006), "Integrating design and retail in the clothing value chain. An empirical study of the organisation of design", International Journal of Operations and Production Management, 26(4)

Adam G. (1971), "New trends in international business: worldwide sourcing and dedomiciling", Acta Oeconomica, 7(3-4)

Baden S. (2002), Trade Policy, Retail Markets and Value Chain Restructuring in the EU Clothing Sector, Prus Working Paper, n. 9.

Belussi F., M. Festa (1990), "L'impresa rete del modello veneto: dal postfordismo al toyotismo? Alcune note illustrative sulle strutture organizzative dell'indotto Benetton”, Oltre il Ponte, 31(3)

Benetton L., A. Lee (1990), Io e i miei fratelli, Sperling \& Kupfer, Milano Benetton Group (anni vari), Bilancio consolidato

Benetton Group (2003), "Benetton presenta la linee guida di sviluppo 20032007",Comunicato stampa 9 dicembre, <www.investorsit.benettongroup.com/ phoenix.zhtml? $\mathrm{c}=142748 \& \mathrm{p}=$ irolnewsArticlePress $\& \mathrm{ID}=475976 \&$ highlight $=>$

Benetton Group (2005), "Approvati dal CdA Benetton i risultati dei primi nove mesi 2005”, Comunicato stampa 11 novembre, $<$ www.investorsit.benettongroup.

$\mathrm{com} /$ phoenix.zhtml?c $=142748 \& \mathrm{p}=$ irolewspress\&nyo $=3>$

Benetton Group (2007), “Analisti finanziari”, 19 settembre

Berger S. (2006), "How we Compete: What Companies Around the World are Doing to Make it in Today's Global Economy", Currency/Doubleday: NewYork

Blois K.J. (1972), "Vertical Quasi Integration", Journal of Industrial Economics , 20

Brusco S. e P. Crestanello (1995), "Tre diversi sistemi produttivi locali: un confronto fra Carpi, Thiene e Benetton”, Oltre il Ponte, 52(4)

Camuffo A., P. Romano e A.Vinelli (2001), "Back to the Future. Benetton Transforms its Global Network”, MIT Sloan Management Review, 43(1)

Ceps (2005), "An Enlarged Community and the Outlook in the Candidate States", Final Report. Part 1. The Textiles and Clothing Industries 
Ciappei C. e A. Sani (2006) Strategie di internazionalizzazione e grande distribuzione nel settore dell'abbigliamento. Focus sulla realtà fiorentina, University Press, Firenze

Crestanello P. (1999), L'industria veneta dell'abbigliamento: internazionalizzazione produttiva e imprese di subfornitura, FrancoAngeli, Milano

Crestanello P. e G. Tattara (2006), "Connessioni e competenze nei processi di delocalizzazione delle industrie venete dell'abbigliamento e delle calzature in Romania”, in G. Tattara G., G. Corò, M. Volpe (a cura di), Andarsene per continuare a crescere, Carocci, Roma

Crestanello P., P. E. Dalla Libera (2003), "La delocalizzazione produttiva all'estero nell'industria della moda: il caso di Vicenza”, Economia e società regionale, $82(2)$

Crestanello P. (2008), "I processi di trasformazione dell'industria dell'abbigliamento”, Economia e società regionale, 101(1)

Dapiran P. (1992), "Benetton. Global Logistics in Action", International Journal of Physical Distribution \& Logistics Management, v.22(6)

Dicken P. (2007), Global Shift. Mapping the changing contours of the world economy, Sage Publications, 5th Edition, London

Dunford M. (2006), "Industrial Districts, Magic Circles, and the Restructuring of the Italian Textiles and Clothing Chain", Economic Geography, 82(1)

European Community Commission (EC) (1996), Communication from the commission. The competitiveness of subcontracting in the textile and clothing industry in the European Union, Com 96.201 final

Favero G. (2005), Benetton. I colori del successo, Egea, Milano

Finger J. M. (1976), "Trade and domestic effects of offshore assembly provision in the U.S. tariff”, The American Economic Review, 66(4)

Finger J. M. (1977), "Offshore Assembly Provision in the West German and Netherlands Tariffs: Trade and Domestic Effects", Weltwirtschaftliches Archiv, 113(2)

Gallaugher J. (2008) "Zara Case: Fast Fashion from Savvy Systems", http://www.gallaugher.com/Zara\%20Case.pdf

Gereffi G., J. Humphrey, T. Sturgeon (2005), "The Governance of Global Value Chain", Review of International Political Economy, 12 (1)

Gomirato E. (2004), "La delocalizzazione dell'abbigliamento in Romania: il caso Stefanel”, Economia e società regionale, 86(2) 
Graziani G. (2001), "International Subcontracting in the Textile and Clothing Industry", in Arndt S.W., Kierzkowsky H., Fragmentation. New Production Patterns in the World Economy, Oxford, Oxford University Press. 209-230

The Hindu Business Line (2007), Trent, Benetton join hands for strategic partnership, (Our bureau) Wednesday, Sep 19, <www.blonnet. com/2007/09/19/ stories/2007091951220500.htm>

Lane D.A. (2004), Innovation led policies for clusters and business networks: Globalization, ontological uncertainty and degeneracy, 23 novembre

Nardin G. (1987), La Benetton. Strategia e struttura di un'impresa di successo. Edirioni lavoro, Roma

$\mathrm{Na}$ Thalang J. (2007), “Outsourcing to India enables Benetton to sell 20\% cheaper", The Nation, 14 maggio <www.nationmultimedia.com/2007/ 05/14/business/business_30034122.php>

Pickles J., A. Smith, M. Bucfik, P. Roukova, R. Begg, (2006), "Upgrading, changing competitive pressures, and diverse practices in the East and Central European apparel industry", Environment and Planning A 38(12)

Sasi A. (2007), “Textile firms leverage Italian tie-ups to move up value chain. For accessing high-end segments of EU, US”, Business Daily from The Hindu

Group of publications, 18 luglio <www.blonnet. com/2007/07/18/ stories/2007071850101100.htm>, Wednesday, New Delhi ???? vedere

Tokatli N. (2008), "Global sourcing: insights from the global clothing industry. The case of Zara, a fast fashion retailer", Journal of Economic Geography, 8(1)

Tunisie (2008), How to invest in Tunisia?, 12 novembre. <www.animaweb. org/en/pays_tunisie_pourquoiinvestir_en.php> 